\section{Abordagem Bioética no Atendimento a Testemunhas de Jeová: conflito entre direito à vida e liberdade religiosa}

\author{
Caldeira, NFC \\ Graduanda do curso de Direito do UniCEUB. e-mail: \\ natfccaldeira@gmail.com
}

\section{Ribeiro, LMN}

Graduando do curso de Medicina do UniCEUB.

\begin{abstract}
Albuquerque, $A$
Cátedra Unesco / Programa de Pós Graduação em Bioética da Universidade de Brasília.
\end{abstract}

PALAVRAS CHAVE: Direitos Humanos; Bioética; Transfusão; Testemunha de Jeová.

Introdução: A luta para a garantia dos Direitos Humanos dos pacientes ainda é um desafio extremamente necessário. Como problemática exemplar sobre o assunto, reiteradamente os pacientes Testemunhas de Jeová são impelidos a se submeterem à transfusão de sangue pelo Poder Judiciário brasileiro, a pedido de hospitais. Assim, os testemunhas de Jeová, em virtude de suas necessidades e vontades mentais e religiosas, somente aceitam receber hemoderivados que tenham como base o sangue autólogo, caso não seja, negam o tratamento ${ }^{1}$. De outro lado, é possível se deparar com a visão de profissionais da área da medicina e de provedores de serviços de saúde que sustentam o dever à vida. Assim, a problemática, no Brasil, se revela conflituosa, tal como explicitado por Kaufmann ${ }^{2}$, ao apontar que a recusa à transfusão de sangue é vista por parte de alguns profissionais da área da saúde como infração ao direito à vida, e até mesmo podendo ser entendida como uma forma de omissão de socorro por parte do profissional. Ademais, a ausência de uma lei que preveja os direitos dos pacientes, incluso o direito à recusa, dificulta o respeito à recusa da submissão à transfusão de sangue dos pacientes Testemunhas de Jeová. Assim, há que se recorrer à Declaração Universal sobre Bioética e Direitos Humanos, de 2005, e à Convenção Americana de Direitos Humanos, de 1969 e ao Pacto Internacional sobre Direitos Civis e Políticos, de 1966, para a proteção do direito à recusa do paciente Testemunha de Jeová. Por outro lado, em vários países do mundo, essa problemática já foi superada há muito tempo, notadamente em virtude do reconhecimento do direito à recusa do paciente. Metodología: Trata-se de pesquisa teórica e documental, que se fundamentou no referencial dos Direitos Humanos dos Pacientes, desenvolvido por Albuquerque ${ }^{3}$, bem no princípio da não-ingerência formulado $\mathrm{Mill}^{4}$, que fundamenta o direito à recusa de tratamentos e procedimentos médicos. Resultados: Conforme o referencial dos Direitos Humanos dos Pacientes, a recusa de tratamentos médicos não é analisada internacionalmente como uma tentativa de suicídio. A questão não há que ser enfrentada sob a ótica do direito à vida, porquanto não os pacientes Testemunhas de Jeová não desejam morrer, mas sim escolher a forma de tratamento e recusar a transfusão de sangue. Atualmente, todas as Legislações sobre Direitos dos Pacientes preveem o direito ao consentimento e à recusa do paciente - Ex. Dinamarca, Estados Unidos, Reino Unido, França, Itália, Canada, Austrália e outros ${ }^{5}$. Portanto, há um consenso legal internacional no sentido de que todo procedimento/tratamento médico se condiciona ao consentimento informado do paciente. Conclusão: Os pacientes Testemunhas de Jeová, possuem o direito de recusar qualquer tratamento sem que seja considerado violação ao direito à vida. A posição do profissional que presta assistência deve ser em concordância com a decisão pessoal do paciente, sem ser considerado omissão de socorro. Dito isso, a liberdade de se posicionar de maneira contrária é de extrema relevância para proteger direitos individuais, não cabe ao Estado e aos médicos julgarem as razões subjacentes à recusa do paciente.

AGRADECIMENTOS.: Ao Centro Universitário de Brasília (UniCEUB). A Clínica de Direitos Humanos do UniCEUB. As nossas famílias.

\section{REFERÊNCIAS}

[1] AZAMBUJA, Letícia Erig Osório de; GARRAFA, Volnei. Testemunhas de Jeová ante o uso de hemocomponentes e hemoderivados. 2010.

[2] KAUFMANN, Roberta Fragoso Menezes. Colisão de direitos fundamentais: $\mathrm{o}$ direito à vida em oposição à liberdade religiosa: o caso dos pacientes Testemunhas de Jeová internados em hospitais públicos. 2007.

[3] LIMA, Rafael Lucas de. John Stuart Mill e o cultivo da individualidade. 2017.

[4] Albuquerque A; Barroso A.Curso de Direitos Humanos. Lumen Juris. Curitiba; 2018.

[5] EUROPEIA, União. União Europeia. 2016. 